\title{
Entrepreneurial Orientation and Innovation Capabilities in Mexican Small Business
}

\author{
Gonzalo Maldonado-Guzman ${ }^{1}$, Sandra Yesenia Pinzon-Castro ${ }^{1} \&$ Ruben Michael Rodriguez-Gonzalez ${ }^{2}$ \\ ${ }^{1}$ Centro de Ciencias Economicas y Administrativas, Universidad Autonoma de Aguascalientes, Mexico \\ ${ }^{2}$ PhD. Student, Centro de Ciencias Economicas y Administrativas, Universidad Autonoma de Aguascalientes, \\ Mexico \\ Correspondence: Gonzalo Maldonado-Guzman, Centro de Ciencias Economicas y Administrativas, Universidad \\ Autonoma de Aguascalientes, Aguascalientes, Mexico, Avenida Universidad No. 940, Ciudad Universitaria, C.P. \\ 20131, Mexico. E-mail: gmaldona@correo.uaa.mx
}

Received: October 17, 2019 Accepted: November 10, $2019 \quad$ Online Published: November 23, 2019

doi:10.5539/jms.v9n2p151 URL: https://doi.org/10.5539/jms.v9n2p151

\begin{abstract}
In an environment of business uncertainty that has characterized the $21^{\text {st }}$ century, enterprises, mainly small and medium-sized ones (SMEs), have to redirect or adequate their business strategies in order to adapt as fast as possible to the changes demanded by the market. Therefore, SMEs have to be more proactive nowadays, take higher risks and be more innovative in order to survive as well as to improve significantly their innovation capabilities in products, services and management systems. In simple terms, SMEs have to adopt and implement the entrepreneurial orientation as part of their everyday activities so they have more possibilities to increase their innovation level. Thus, the main objective of this research is to analyze the existing relation between proactivity, risk taking and innovativeness (dimensions of the entrepreneurial orientation) with the innovation capabilities (innovation in products, services and management systems). The results obtained show that there is a positive and significant relation among the three dimensions of entrepreneurial orientation and innovation capabilities.
\end{abstract}

Keywords: entrepreneurial orientation, innovation, capabilities, small business

\section{Introduction}

In the current literature of business and management sciences there is still a considerable debate among researchers, scholars and professionals of the business field about why some enterprises attain better results than others even when they apply the same type of business strategies (Oly \& Agarwal, 2014). There is a variety of arguments that attempt to provide a convenient and logical explanation and among the most accepted ones in the literature is that only some firms obtain sustainable competitive advantages through the development of innovation capabilities and the ability for their adoption and implementation (Oly \& Agarwal, 2014). Consequently, the theory of dynamic capabilities provides a theoretical explanation of why an increasing number of enterprises achieve more competitive advantages by using their resources and capabilities efficiently (Wernerfelt, 1984; Teece, Pisano, \& Shuen, 1997; Eisenhardt \& Martin, 2000; Makadok, 2001; Newbert, 2007; Nasution, Mavondo, Matanda, \& Ndubisi, 2011).

However, and despite the importance of resources and capabilities in organizations, especially in small and medium-sized enterprises (SMEs), a high percentage of theoretical and empirical investigations published in the literature have focused in the analysis and discussion of the relation of these capabilities in big enterprises which are mostly ignored in the researches focused in SMEs (Oly \& Agarwal, 2014). Therefore, the investigations about entrepreneurial orientation and innovation capabilities in SMEs are increasing in the current literature because of the importance of SMEs for the growth and development of the economy and society of any country in the world, especially in developing countries with emerging economies as it is the case of Mexico (Mueller, Rosenbusch, \& Bausch, 2013).

In this regard, the existing relation between entrepreneurial orientation and innovation capabilities represent an opportunity so researchers and scholars can develop future investigations that allow them to provide theoretical and empirical evidence of the actions of entrepreneurism and the level of innovation in SMEs (Yuan, Hermens, Huang, \& Chelliah, 2015). Thus, even when SMEs usually have several restrictions of resources, they are the 
kind of enterprise that better react to changes demanded by the market by adopting and implementing innovation activities since SMEs usually have a lot of potential that can facilitate not only the innovation activities but also the development of an entrepreneurial orientation (Tang \& Hull, 2012; Prajogo \& McDermott, 2014).

Similarly, enterprises, especially SMEs, need to improve their entrepreneurial orientation as well as increase significantly their innovation capabilities in products, services and management systems in order to survive and prevail in a highly competitive business environment (Kreiser, Marino, Dickson, \& Weaver, 2010). By having several limitations regarding human, technical and financial resources, SMEs depend basically on their growth, development, improvement and level of business performance of the skills they have to adopt and implement both the entrepreneurial orientation and the innovation capabilities in products, services and management systems (Mbizi, Hove, Thondhlana, \& Kakava, 2013; Mazzarol, Clarck, \& Reboud, 2014).

Even when there is a high percentage of theoretical and empirical investigations that link innovation capabilities with business performance of SMEs, there are relatively few investigation papers that have analyzed and discussed the existing influence between the dimensions of entrepreneurial orientation and innovation capabilities of SMEs (Yuan et al., 2015). Therefore, the main contribution of this empirical research is the analysis of the existing relation between the dimension of the entrepreneurial orientation and innovation capabilities of SMEs in a country with an emerging economy as it is the case of Mexico. The rest of the research is organized in the following parts: the second section examines the theoretical framework and the presentation of the research hypotheses; the third section shows the methodology, the sample and the variables used; the fourth section analyzes the results obtained and, finally, the fifth section shows the main conclusions and the research discussion.

\section{Method}

In the current literature of business and management sciences, several researchers and scholars have considered that entrepreneurial orientation adopted and implemented by SMEs is a key element that can explain the differences in innovation capabilities as well as the business performance of the firms (Knight, 2000; Jantunen, Puumalainen, Saarenketo, \& Kylaheiko, 2005; Street \& Cameron, 2007). Similarly, there is another group of researchers and scholars that suggest that entrepreneurial orientation is one of the most important capabilities that enterprises can have, mostly SMEs (Lumpkin \& Dess, 1996; Álvarez \& Busenitz, 2001; Teng, 2007). A third group claims that entrepreneurial orientation of SMEs will provide them with the necessary capabilities to produce more and better competitive advantages (Lee, Lee, \& Pennings, 2001; Wiklund \& Shepherd, 2003).

In this regard, the entrepreneurial orientation can be considered as an essential strategy that allows SMEs to anticipate to the changes demanded by the market and the external context of business in order to achieve better results as well as to increase the innovation capabilities of organizations (Covin \& Slevin, 1991; Lumpkin \& Dess, 1996). Moreover, the entrepreneurial orientation provides SMEs with the necessary capabilities and skills to use internal resources in an adequate and efficient way, including innovation, and a more efficient use of internal resources (Wiklund \& Shepherd, 2003). Therefore, SMEs that have entrepreneurial orientation are more suitable to increase their innovation capabilities in products, services and management systems as well as diversify their business activities in national and international markets (Knight, 2000; Dimitratos, Lioukas, \& Carter, 2004).

Likewise, several researchers, scholars and professionals of the business areas consider that entrepreneurial orientation is specifically important for SMEs for two main reasons. Firstly, because of their reduced size, SMEs usually have very limited human, financial, technical and management resources ( $\mathrm{Lu} \&$ Beamish, 2001; Brouthers, Nakos, Hadjimarcou, \& Bouthers, 2009). As a result, entrepreneurial orientation provides SMEs with the necessary resources and capabilities not only to use efficiently and effectively the limited resources they have but also to improve significantly the access to additional resources that are outside the organization (Wiklund \& Shepherd, 2003).

Secondly, there is only a small number of SMEs that have patents or state-of-the-art technology in their production processes but at the same time they do not have good experience in the commercialization of their products in national and international markets. They do not have enough technological experience, marketing or innovation as well as a very low offer of products and a low level of public recognition and ranking of their brands, among other main problems (Lu \& Beamish, 2001; Berthon, Ewing, \& Napoli, 2008). For this reason, some investigations recently published in the literature establish that entrepreneurial orientation is one of the basic capabilities that SMEs can use to improve or obtain more and better competitive advantages as well as a higher level of innovation (Lee et al., 2001; Wiklund \& Shepherd, 2003).

In a more specific aspect, SMEs can increase significantly their innovation capabilities in products, services and 
management systems if they are willing to explore new ideas, ways to carry out their activities or new ways to solve their problems or, in other words, the adoption and implementation of the entrepreneurial orientation (Lumpkin \& Dess, 1996). Therefore, the SMEs that can create an adequate environment inside the organization for the implementation and development of an entrepreneurial orientation will have higher possibilities of increasing significantly their innovation capabilities as well as expand their commercial activities to other regional, national, and even international markets (Knight, 2000; De Clercq, Sapienza, \& Crijns, 2005).

As a result, the innovation capabilities in products, services and management systems obtained by SMEs will provide them with more and better business strategies that can influence in a change in the organizational structure in a way that facilitates the elimination of barriers associated to innovation activities and the achievement of better results in enterprises (Knight, 2000). Therefore, SMEs will be more innovative when they develop more and better capabilities in their entrepreneurial orientation as well as in the adaptation of their products to the preferences and needs of their clients and consumers. This will facilitate the attainment of a higher level of business performance as well as other types of benefits such as the very survival of the SME in its market (Zahra \& Garvis, 2000).

In this trend of ideas, McDougall and Oviatt (2000) concluded that entrepreneurial orientation can be defined as a combination of innovative, proactive behaviors and risk taking that organizations carry out, especially SMEs, which produce a higher value in the products created by enterprises. Thus, by adopting and implementing the entrepreneurial orientation, SMEs will have higher possibilities of creating an organizational structure that is entrepreneurial and all the members of the company will be able to be entrepreneurs which will create a synergy in their everyday activities (Echols \& Neck, 1998). Consequently, the entrepreneurial orientation is usually characterized and easily distinguished by the entrepreneurial processes of risk taking (McClelland, 1961; Miller, 1983; Ndubisi et al., 2005), innovativeness (Hornaday \& Abound, 1971; Dunkelberg \& Cooper, 1982; Miller, 1983) and proactivity (Miller, 1983; Echols \& Neck, 1998; Nasution et al., 2011).

Moreover, Miller (1983) considered that the amount of entrepreneurial orientation depends on the innovation, risk taking and proactivity that organizations have. In other words, the more risks enterprises take; the more innovation capabilities they have and the more proactive they are the higher their level of entrepreneurial orientation they will have. In a similar trend of ideas, Matsuno, Mentzer and Ozsomer (2002) concluded that the entrepreneurial orientation allows enterprises, including SMEs, to obtain better results and the necessary skills to improve their commercial and market activities which reduce uncertainty and risks. Therefore, a SME can be labeled as entrepreneurial if it is proactive to obtain more benefits than their main competitors (Oly \& Agarwal, 2014), if it takes risks in decision making of the demand of the market (Barrett, Balloun, \& Weinstein, 2003), and if it is innovative in the development of their activities (Dunkelberg \& Cooper, 1982; Miller, 1983).

In this regard, proactivity is usually considered as the level that companies have in the development of their activities that allow them to survive in a highly changing market, especially SMEs which have important limitations of resources and investment capacity when compared with big enterprises; this limits the attainment of sustainable competitive advantages and in the innovation capabilities (Yuan et al., 2015). Thus, proactivity is the capability that SMEs have to take advantage of using their resources and innovation capabilities suitably to get more and better competitive advantages as well as different benefits that the market offers (Ireland, Kuratko, \& Morris, 2006; Eggers, Kraus, Hughes, Laraway, \& Snycerski, 2013).

Additionally, proactivity is also considered in the literature as one of the essential activities to achieve a higher level of innovation in SMEs since this type of entrepreneurial orientation tends to create a higher innovation capability in enterprises to fulfill the requirements and needs of consumers or the market demand (Nieto, Santamaria, \& Fernandez, 2015) since the innovation of new products or processes, or the improvement of products, services and management systems, or the creation of new markets have a direct relation with the proactivity of a SME (Yuan et al., 2015). Therefore, the increase of innovation capabilities can have their origin in an adequate use of the capabilities of the entrepreneurial orientation as it is the case of proactivity (Nieto et al., 2015).

Similarly, it has been acknowledged in the literature of business and management sciences that the increase on the level of innovation in in products, services and management systems is commonly associated to the rise of the efficiency of the proactivity that organizations have, especially SMEs (Chang \& Hughes, 2012). Thus, the increase of the level of innovation of SMEs does not depend only on the existence of new knowledge and learning in the organization but also the existence of several proactive capabilities, structures and entrepreneurial processes that SMEs have (Jensen et al., 2006; Chang \& Hughes, 2012; Nieto et al., 2015; Saki, Shakiba, \& Savari, 2013). Thus, considering the information presented above, it is possible to establish the following 
hypothesis:

\section{H1: The higher the level of proactivity, the higher the level of innovation}

Risk taking is another dimension of entrepreneurial orientation that also has a positive and significant influence in innovation activities of SMEs. Risk taking is generally considered in the literature as a combination of good intentions and a series of activities that enterprises frequently do to improve their results and increase their innovation capabilities (Yuan et al., 2015). These capabilities include the innovation in products, services and management systems as well as the investment of opening new markets that can create more and better results for organizations (Baker \& Sinkula, 2009). That is why risk taking is an essential activity that forces managers to use the available resources efficiently and take advantage of the opportunities that the market offers to obtain better results (Ireland et al., 2006; Nasution et al., 2011; Eggers et al., 2013).

Thus, Hughes and Morgan (2007) concluded that the entrepreneurial orientation implies the idea that organizations adopt it and implement it as they are already taking some risks that are necessary to achieve a higher level of growth in a highly competitive market. A few years earlier, McGrath (2001) had already considered this situation and argued that business that have a higher level of business performance are those that took higher risks and they also got a potential to create higher levels of profit and innovation. Similarly, Dess, Pinkham and Yang (2011) as well as Tang, Tang and Katz (2014) arrived to the conclusion in their corresponding investigations that risk taking has a positive and significant influence for both the growth of the organization and innovation capabilities.

Additionally, risk taking and innovation capabilities are closely linked through the adoption and implementation of entrepreneurial orientation, which in turn has a positive and significant impact on the growth of enterprises (Yuan et al., 2015). Furthermore, the innovation in products, services and management systems can be a form of risk taking in itself because, according to Hoonsopon and Ruenrom (2012), risk-taking turn has a positive and significant impact on the innovation capabilities of SMEs. Therefore, SMEs with high level of entrepreneurial risk taking can have opportunities that facilitate the development of innovation capabilities by offering new or improved products manufactured with new processes and management systems with low costs for different markets (Zhou, Yim, \& David, 2005; Hoonsopon \& Ruenrom, 2012). Thus, considering the information presented above, it is possible to establish the following hypothesis:

\section{H2: The higher the level of risks, the higher the level of innovation}

Regarding the innovation capability that enterprises have, it can be considered in the literature of business and management sciences as the capability and intention that organizations have, especially SMEs, of creating new products and/or services through new processes (Yuan et al., 2015). Therefore, innovativeness can be defined as the capability that enterprises and workers have, each entity individually, regarding the creativity and its implementation to create new or improved products, services and processes (Mbizi et al., 2013). By considering this definition, it is possible to state that innovativeness is an essential capability that SMEs have in order to produce radical or incremental changes in existing products, services and processes in the organization (Yuan et al., 2015).

In this regard, several researchers and scholar consider that innovativeness and innovation capability are two different aspects in the growth and development of business. For example, Kaplinsky and Morris (2003) concluded that innovation capability can be regarded as a process through which enterprises improve their products, processes and management systems in order to obtain a continuous improvement and better results. Similarly, Giuliani, Pietrobelli and Rabellotti (2003) determined that innovativeness can be considered as a function of SMEs that they could use to increase significantly the value of the business or brand along with entering in new markets, sectors or market niches through the creation of new products and/or services.

For this reason, the innovation capability commonly describes the implementation of the creative capability that SMEs have to achieve a higher level of growth and development (Lyons, Chatman, \& Joyce, 2007). On the other hand, innovativeness describes the processes to create original products through the use of methodologies that are usually employed to put into practice the ideas of the organization (Roberts, 1999). Therefore, it is possible to find theoretical and empirical evidence that shows that innovativeness has a direct and positive relation with innovation capability (Hamel, 2000; Hitt, Ireland, Camp, \& Sexton, 2001; Lyons et al., 2007). Considering the information presented above, it is possible to establish the following hypothesis:

\section{H3: The higher the level of innovativeness, the higher the level of innovation}

In order to prove the hypotheses established in this research, an empirical investigation was implemented by using the business directory of the Sistema de Información Empresarial de México 2014 (Business Information 
System of Mexico) as a reference framework, which had 6,194, registered companies in June 2014. For practical purposes of this empirical research, the only enterprises that were considered were the ones that had between 5 and 250 employees and for this reason the directory was reduced to 1,260 SMEs and a sample of 300 SMEs was obtained. The questionnaire was designed to be answered by the managers and/or owners of SMEs and it was carried out as a personal interview to each of the 300 enterprises which were selected randomly with a sampling error of $\pm 4.5 \%$ and a reliability level of $95 \%$. The interviews with the managers were carried out from January to March 2015.

Similarly, a scale proposed by Miller (1983) was used to measure the three dimensions of entrepreneurial orientation. He considered that this orientation can be measured in three dimensions: proactivity (measured by means of a six-item scale); risk taking (measured by means of a six-item scale); and innovativeness (measured by means of a six-item scale). Regarding the measurement of innovation capabilities, a scale from the OECD (OECD, 2005) was considered which establishes that this aspect can be measured by means of a three-item scale; product innovation in can be measured by means of a two-item scale, processes innovation can be measured by means of a two-item scale and management systems innovation can be measured by means of a three-item scale. All the items of the scales used in this research were measured by means of a five-point Likert scale (from $1=$ Totally agree to $5=$ Totally disagree) as its limits.

Likewise, in order to evaluate the reliability and validity of the scales used in the research, a Confirmatory Factorial Analysis (CFA) was carried out by using the method of maximum likelihood with the software EQS 6.1 (Bentler, 2005; Brown, 2006; Byrne, 2006). Moreover, the reliability of the scales was evaluated by means of Cronbach's alpha and the Composite Reliability Index (CRI) suggested by Bagozzi and Yi (1988). The suggestions of Chou, Bentler and Satorra (1991) as well as of Hu, Bentler and Kano (1992) were taken into consideration regarding the correction of the statistics of the theoretical model when it is considered that the normality of data is present by using also the robust statistics in order to provide a better statistical adjustment of data (Satorra \& Bentler, 1988).

The CFA results are shown in Table 1 and they indicate that the theoretical model has a good statistical adjustment of data $\left(S-B X^{2}=311.014 ; d f=199 ; p=0.000 ; N F I=0.901 ; N N F I=0.955 ; C F I=0.962 ; R M S E A=\right.$ $0.043)$. All the items of related factors are significant $(\mathrm{p}<0.01)$. The size of all the standardized factorial loads are above 0.60 (Bagozzi \& Yi, 1988). Cronbach's alpha and CRI have a value above 0.70 and the Extracted Variance Index (EVI) has a value above 0.50 (Fornell \& Larcker, 1981). These values indicate that there is sufficient evidence of convergent validity and reliability, which justifies the internal reliability of the scales used (Nunally \& Bernstein, 1994; Hair et al., 1995).

Table 1. Internal consistency and convergent validity of the theoretical model

\begin{tabular}{|c|c|c|c|c|c|c|}
\hline Variable & Indicator & Factorial Loading & Robust t-Value & Cronbach's Alpha & CRI & EVI \\
\hline \multirow[t]{5}{*}{ Proactivity } & PR1 & $0.675^{* * *}$ & $1.000^{\mathrm{a}}$ & 0.841 & 0.843 & 0.519 \\
\hline & PR2 & $0.719 * * *$ & 10.836 & & & \\
\hline & PR4 & $0.721 * * *$ & 11.194 & & & \\
\hline & PR5 & $0.739 * * *$ & 11.223 & & & \\
\hline & PR6 & $0.745 * * *$ & 11.873 & & & \\
\hline \multirow[t]{5}{*}{ Risk Taking } & TR1 & $0.662 * * *$ & $1.000^{\mathrm{a}}$ & 0.852 & 0.853 & 0.539 \\
\hline & TR2 & $0.648 * * *$ & 8.070 & & & \\
\hline & TR4 & $0.791 * * *$ & 9.130 & & & \\
\hline & TR5 & $0.788 * * *$ & 9.664 & & & \\
\hline & TR6 & $0.768 * * *$ & 9.477 & & & \\
\hline \multirow[t]{5}{*}{ Innovativeness } & IN1 & $0.716^{* * *}$ & $1.000^{\mathrm{a}}$ & 0.857 & 0.859 & 0.551 \\
\hline & IN2 & $0.628 * * *$ & 12.555 & & & \\
\hline & IN3 & $0.790 * * *$ & 12.645 & & & \\
\hline & IN4 & $0.749 * * *$ & 11.307 & & & \\
\hline & IN5 & $0.813 * * *$ & 14.631 & & & \\
\hline \multirow[t]{3}{*}{ Innovation } & IP1 & $0.826 * * *$ & 15.155 & 0.897 & 0.898 & 0.748 \\
\hline & IR2 & $0.953 * * *$ & 19.726 & & & \\
\hline & IG3 & $0.808 * * *$ & 11.579 & & & \\
\hline \multicolumn{7}{|c|}{$S-B X^{2}(\mathrm{df}=199)=311.014 ; \mathrm{p}<0.000 ; \mathrm{NFI}=0.901 ; \mathrm{NNFI}=0.955 ; \mathrm{CFI}=0.962 ; \mathrm{RMSEA}=0.043$} \\
\hline
\end{tabular}


Regarding the discriminant validity of the theoretical model of intellectual property and innovation, the evidence is presented in two ways that can be observed in Table 2. Firstly, a reliability interval test is presented, proposed by Anderson and Gerbing (1988), which establishes that with an interval of $95 \%$ of reliability none of the individual latent elements of the matrix of correlation contains the value of 1.0. Secondly, the extracted variance test, proposed by Fornell and Larcker (1981) establishes that the EVI value of each pair of constructs must be higher than their corresponding square covariance. Therefore, according to the results obtained from both tests, it can be concluded that both measurements provide enough evidence of discriminant validity of the theoretical model.

Table 2. Discriminant validity of the theoretical model

\begin{tabular}{lllll}
\hline Variables & Proactivity & Risk Taking & Innovativeness & Innovation \\
\hline Proactivity & $\mathbf{0 . 5 1 9}$ & 0.120 & 0.190 & 0.077 \\
Risk Taking & $0.242-0.450$ & $\mathbf{0 . 5 3 9}$ & 0.166 & 0.095 \\
Innovativeness & $0.324-0.548$ & $0.274-0.542$ & $\mathbf{0 . 5 5 1}$ & 0.092 \\
Innovation & $0.184-0.372$ & $0.203-0.415$ & $0.195-0.411$ & $\mathbf{0 . 7 4 8}$ \\
\hline
\end{tabular}

The diagonal represents the Extracted Variance Index (EVI), whereas above the diagonal the variance is presented (squared correlation). Below diagonal, the estimated correlation of factors is presented with $95 \%$ confidence interval.

\section{Results}

A model of structural equations was applied in order to answer the hypotheses stated in this empirical research by using the software EQS 6.1 (Bentler, 2005; Brown, 2006; Byrne, 2006) which analyzed the nomological validity of the theoretical model through the square Chi test. It was based on the comparison of the results obtained from the theoretical model and the measurement model; the results indicate that the differences between the two-theoretical model and the measurement model are not significant which provides an explanation of the relations observed between the latent constructs (Anderson \& Gerbing, 1988; Hatcher, 1994). Table 3 shows these results in a more detailed way.

Table 3. Results from the structural equations model

\begin{tabular}{llll}
\hline Hypothesis & Structural Relationship & Standardized Coefficient & Robust t-Value \\
\hline $\begin{array}{l}\text { H1: Higher level of proactivity, higher level of } \\
\text { innovation. }\end{array}$ & Proactivity $\rightarrow$ Innovation & $0.303^{* * *}$ & 3.348 \\
$\begin{array}{l}\text { H2: Higher level of risk taking, higher level of } \\
\text { innovation. }\end{array}$ & Risk Taking $\rightarrow$ Innovation & $0.415^{* * *}$ & 4.345 \\
$\begin{array}{l}\text { H3: Higher level of innovativeness, higher level } \\
\text { of innovation. }\end{array}$ & Innovativeness $\rightarrow$ Innovation & $0.349^{* * *}$ & 3.739 \\
$S-B X^{2}(\mathrm{df}=199)=313.182 ; \mathrm{p}<0.000 ; \mathrm{NFI}=0.901 ; \mathrm{NNFI}=0.955 ; \mathrm{CFI}=0.961 ; \mathrm{RMSEA}=0.044$ & \\
\hline Note. $* * *=\mathrm{P}<0.01$.
\end{tabular}

Table 3 shows the results obtained from the implementation of the model of structural equations. It was found that, regarding hypothesis $\mathbf{H 1}$, the results $(\beta=0.303, \mathrm{p}<0.01)$ indicate that proactivity has significant positive results in the innovation of SMEs. Regarding hypothesis $\mathbf{H 2}$, the results $(\beta=0.415, \mathrm{p}<0.01)$ indicate that risk taking has significant positive results in the innovation of SMEs. Regarding hypothesis $\mathbf{H 3}$, the results $(\beta=0.349$, $\mathrm{p}<0.01)$ indicate that innovativeness has significant positive results in the innovation of SMEs. Therefore, it is possible to conclude that, on one hand, proactivity, risk taking and innovativeness create a higher level of innovation in SMEs. On the other hand, the entrepreneurial orientation is a good estimator of innovation capabilities in enterprises, especially in SMEs.

\section{Discussion}

The results obtained in this research paper allow us to reach some conclusions on two essential aspects. Firstly, the more proactive SMEs are in their business activities the higher the possibilities to increase significantly their innovation capabilities. If they become reactive to the changes demanded by the business context and the market, it will be too complicated to increase their innovation capabilities. Similarly, they will have to take higher risks in the development of their activities as this will also help them to improve their innovation level. Finally, they 
will have to be innovative, that is, to take advantage of their capabilities and creativity to improve or create new products, services and management systems since their innovation capabilities will depend mostly on the proactivity actions, risk taking and innovativeness that they have and apply in their daily activities.

Secondly, it is also possible to conclude that as long as SMEs apply a higher proactivity, take more risks and become more innovative then this type of organizations will have higher possibilities to adopt and implement an entrepreneurial orientation. This will result into a more entrepreneurial organization with more entrepreneurial employees and workers, which will bring a higher level of innovation capabilities as well as a higher business performance. Therefore, if enterprises want to improve or increase significantly their innovation capabilities then, as a first step, they will have to implement inside the organization an entrepreneurial orientation by applying specifically its three dimensions: proactivity, risk taking and innovativeness and make them part of their everyday activities.

Additionally, these results also involve a series of implication for both enterprises in general as well as managers and/or owners of SMEs specifically. Thus, one of the first implications of this research is that enterprises have to change their traditional organizational culture and implement an entrepreneurial orientation in which workers and employees of SMEs can offer ideas to solve the main problems that affect the organization. This will give the personnel a more proactive participation working as a team and provide ideas for the improvement or development of new products, processes and management systems. In turn, this will improve significantly not only the innovation capabilities of SMEs but also the results they can have.

Similarly, the change of organizational culture demands that SMEs create a positive environment so employees and workers can participate with their ideas and work as a team to improve the organization, otherwise it will be too difficult that the staff feel safe to express their ideas since they will be afraid of being punished. Therefore, it is very important that the internal context in the organization facilitates the creation of ideas and the implementation of creativity from all the personnel so this can produce a higher level of proactivity in SMEs instead of being just reactive to the problems and demands of the business and market environment, take better decisions with low risks and create a higher level of innovativeness. In other words, it is important that SMEs adopt and implement the entrepreneurial orientation in all the activities and functional areas or departments of the organization.

Likewise, managers and/or owners of SMEs will have to carry out the necessary action to create a positive environment for the creation of ideas and the development of creativity of all the organization. This will allow them to adopt and implement efficiently and effectively the entrepreneurial orientation. In other words, employees and workers will need some freedom to develop their creativity and propose not only solution to problems face by the organization but also to produce new or improved products, services and management systems so their products and/or services can adapt to the preferences and needs demanded by their current and potential customers. These actions could displace their main competitors of their market which will create a higher level of growth and development in the organization.

Furthermore, if managers and/or owners of SMEs carry out relevant actions so the organizations have the requirements to adopt and implement efficiently all the activities related to the entrepreneurial orientation then enterprises will have higher possibilities to increase significantly their innovation capabilities as well as their creative and entrepreneurial capability. With this, SMEs will have higher possibilities to adopt and implement innovation capabilities in all the organization which will allow them to increase their participation in the market and survive and also obtain more and better competitive advantages, a higher level of competitiveness and a better level of business performance than their main competitors.

Finally, the implementation entrepreneurial orientation will be fundamental for an adequate implementation of proactivity, risk taking and the creation of a higher level of innovativeness so managers and/or owners of SMEs design and implement the necessary training and skill-building courses so workers and employees of the organization improve and increase their creative capability, develop their team working capabilities, share their knowledge and skills in a way that facilitates not only their personal development but also an effective and efficient integration of all the personnel of the organization. This will enable the growth of innovation capabilities as well as a rise in the level of business performance in SMEs.

On the other hand, it is important to consider the main implications that this empirical research has. The first one is related to the scales used to measure the entrepreneurial orientation and the innovation capabilities since only three dimensions or factors were considered for both the entrepreneurial orientation (proactivity, risk taking and innovativeness) and the innovation capabilities (innovation in products, processes and management systems). Future investigations will need to incorporate other factors or dimensions to verify the results obtained. A second 
limitation is the information obtained as only qualitative variables were considered to measure the two constructs related (entrepreneurial orientation and innovation capabilities). Further researches will need to incorporate quantitative variables or hard data in order to verify if the results obtained are the same.

A third limitation is that the questionnaire was applied only to managers and/or owners of SMEs from Aguascalientes State so the results obtained can vary if a different sample is used. Further investigations will need to apply the same questionnaire to, for example, workers and employees to verify the results obtained. A fourth limitation is that for the sample the enterprises considered were only those that had between five and 250 workers and as a consequence future researcher will have to consider in the sample SMEs with less than five employees. A final limitation is that most managers and/or owners of SMEs from Aguascalientes State considered that the information requested was confidential so the information provided does not necessarily reflect the reality of the enterprises.

\section{References}

Alvarez, S. A., \& Busenitz, L. W. (2001). The entrepreneurship of resource-based theory. Journal of Management, 27(6), 755-775. https://doi.org/10.1177/014920630102700609

Anderson, J., \& Gerbing, D. (1988). Structural equation modeling in practice: A review and recommended two-step approach. Psychological Bulletin, 13, 411-423. https://doi.org/10.1037/0033-2909.103.3.411

Bagozzi, R. P., \& Yi, Y. (1988). On the evaluation of structural equation models. Journal of the Academy of Marketing Science, 16(1), 74-94. https://doi.org/10.1007/BF02723327

Baker, W. E., \& Sinkula, J. M. (2009). The complementary effects of market orientation and entrepreneurial orientation on profitability in small business. Journal of Small Business Management, 47(4), 443-464. https://doi.org/10.1111/j.1540-627X.2009.00278.x

Barrett, H., Ballou, J., \& Weinstein, A. (2003). Success factors for entrepreneurial organizations. UIC Research Symposium Papers, University of Illinois Institute for Entrepreneurial Studies, Chicago, IL.

Bentler, P. M. (2005). EQS 6 structural equations program manual. Encino, CA: Multivariate Software.

Berthon, P., Ewing, M. T., \& Napoli, J. (2008). Brand management in small to medium-sized enterprises. Journal of Small Business Management, 46(1), 27-45. https://doi.org/10.1111/j.1540-627X.2007.00229.x

Brouthers, K. D., Nakos, G., \& Dimitratos, P. (2015). SME entrepreneurial orientation, international performance, and the moderating role of strategic alliances. Entrepreneurship: Theory \& Practice, 39(5), 1161-1187. https://doi.org/10.1111/etap.12101

Brouthers, L., Nakos, G., Hadjimarcou, J., \& Brouthers, K. D. (2009). Key factors for successful export performance for small firms. Journal of International Marketing, 17(3), 21-38. https://doi.org/10.1509/jimk.17.3.21

Brown, T. (2006). Confirmatory factor analysis for applied research. New York, NY: The Guilford Press.

Byrne, B. (2006). Structural equation modeling with EQS, basic concepts, applications, and programming (2nd ed.). London: LEA Publishers.

Chang, Y. Y., \& Hughes, M. (2012). Drivers of innovation ambidexterity in small to medium-sized firms. European Management Journal, 30(1), 1-17. https://doi.org/10.1016/j.emj.2011.08.003

Chou, C. P., Bentler, P. M., \& Satorra, A. (1991). Scaled test statistics and robust standard errors for nonnormal data in covariance structure analysis. British Journal of Mathematical and Statistical Psychology, 44, 347 357. https://doi.org/10.1111/j.2044-8317.1991.tb00966.x

Covin, J. G., \& Slevin, D. P. (1991). A conceptual model of entrepreneurship as firm behavior. Entrepreneurship Theory \& Practice, 16(1), 7-26. https://doi.org/10.1177/104225879101600102

De Clercq, D., Sapienza, H. J., \& Crijns, H. (2005). The internationalization of small and medium-sized firms. Small Business Economics, 24(4), 409-419. https://doi.org/10.1007/s11187-005-5333-x

Dess, G. G., Pinkham, B. C., \& Yang, H. (2011). Entrepreneurial orientation: assessing the construct's validity and addressing some of its implications for research in the areas of family business and organizational learning. Entrepreneurship: Theory \& Practice, 35(5), 1077-1090. https://doi.org/10.1111/j.1540-6520.2011.00480.x

Dimitratos, P., Lioukas, S., \& Carter, S. (2004). The relationship between entrepreneurship and international performance: The importance of domestic environment. International Business Review, 13(1), 19-41. 
https://doi.org/10.1016/j.ibusrev.2003.08.001

Dunkelberg, W. C., \& Cooper, A. C. (1982). Entrepreneurial typologies. In K. H. Vesper (Ed.), Frontiers of Entrepreneurship Research. Wellesley, MA: Babson Centre for Entrepreneurial Studies.

Echols, A. E., \& Neck, C. P. (1998). The impact of behaviors and structure on corporate entrepreneurial success. Journal of Management Psychology, 13(1/2), 38-46. https://doi.org/10.1108/02683949810369110

Eggers, F., Kraus, S., Hughes, M., Laraway, S., \& Snycerski, S. (2013). Implications of customer and entrepreneurial orientations for SME growth. Management Decision, 51(3), 524-546. https://doi.org/10.1108/00251741311309643

Eisenhardt, K. M., \& Martin, J. A. (2000). Dynamic capabilities: What are they? Strategic Management Journal, $21(10 / 11)$, https://doi.org/10.1002/1097-0266(200010/11)21:10/11<1105::AID-SMJ133>3.0.CO;2-E

$1105-1121$.

Fornell, C., \& Larcker, D. (1981). Evaluating structural equation models with unobservable variables and measurement error. Journal of Marketing Research, 18, 39-50. https://doi.org/10.1177/002224378101800104

Giuliani, E., Pietrobelli, C., \& Rabellotti, R. (2003). Upgrading in global value chains: Lessons from Latin American clusters. World Development, 33(4), 549-573. https://doi.org/10.1016/j.worlddev.2005.01.002

Hair, J. F., Anderson, R. E., Tatham, R. L., \& Black, W. C. (1995). Multivariate data analysis with readings. New York, NY: Prentice-Hall.

Hamel, G. (2000). Leading the Revolution. Cambridge, MA: Harvard University Press.

Hatcher, L. (1994). A step-by-step approach to using the SAS system for factor analysis and structural equation modeling. Cary, NC: SAS Institute Inc.

Hitt, M. A., Ireland, R. D., Camp, S. M., \& Sexton, D. L. (2001). Guest editors' introduction to the special issue strategic entrepreneurship: Entrepreneurial strategies for wealth creation. Strategic Management Journal, 22(1), 479-491. https://doi.org/10.1002/smj.196

Hoonsopon, D., \& Ruenrom, G. (2012). The impact of organizational capabilities on the development of radical and incremental product innovation and product innovation performance. Journal of Management Issues, 24(3), 250-276.

Hornaday, J. A., \& Abound, J. (1971). Characteristics of successful entrepreneurs. Personnel Psychology, 24(2), 141-153. https://doi.org/10.1111/j.1744-6570.1971.tb02469.x

Hu, L. T., Bentler, P. M., \& Kano, Y. (1992). Can test statistics in covariance structure analysis be trusted? Psychological Bulletin, 112, 351-362. https://doi.org/10.1037//0033-2909.112.2.351

Hughes, M., \& Morgan, R. E. (2007). Deconstructing the relationship between entrepreneurial orientation and business performance at the embryonic state of firm growth. Industrial Marketing Management, 36(5), 651-661. https://doi.org/10.1016/j.indmarman.2006.04.003

Ireland, R. D., Kuratko, D. F., \& Morris, M. H. (2006). A health audit for corporate entrepreneurship: Innovation at all levels (Part II). Journal of Business Strategy, 27(2), 21-29. https://doi.org/10.1108/02756660610650019

Jansen, J. J. P., Van Den Bosch, F. A. J., \& Volberda, H. W. (2006). Exploratory innovation, exploitative innovation, and performance: Effects of organizational antecedents and environmental moderators. Management Science, 52(11), 1661-1674. https://doi.org/10.1287/mnsc.1060.0576

Jantunen, A., Puumalainen, K., Saarenketo, S., \& Kylaheiko, K. (2005). Entrepreneurial orientation, dynamic capabilities and international performance. Journal of International Entrepreneurship, 3(3), 600-633. https://doi.org/10.1007/s10843-005-1133-2

Kaplinsky, R., \& Morris, M. (2003). A Handbook for Value Chain Research. Canada: International Development Research Centre.

Knight, G. (2000). Entrepreneurship and marketing strategy: The SME under globalization. Journal of International Marketing, 8(2), 12-31. https://doi.org/10.1509/jimk.8.2.12.19620

Kreiser, P. M., Marino, L. D., Dickson, P., \& Weaver, K. M. (2010). Cultural influences on entrepreneurial orientation: The impact of national culture on risk taking and proactiveness in SMEs. Entrepreneurship: Theory \& Practice, 34(5), 959-983. https://doi.org/10.1111/j.1540-6520.2010.00396.x 
Lee, C., Lee, K., \& Pennings, J. M. (2001). Internal capabilities, external networks, and performance: A study on technology-based ventures. Strategic Management Journal, 22(6), 615-640. https://doi.org/10.1002/smj.181

Lu, J., \& Beamish, P. (2001). The internationalization and performance of SMEs. Strategic Management Journal, 22(6/7), 565-586. https://doi.org/10.1002/smj.184

Lumpkin, G. T., \& Dess, G. G. (1996). Clarifying the entrepreneurial orientation construct and linking it to performance. Academy of Management, 21(1), 135-173. https://doi.org/10.2307/258632

Lyons, R. K., Chatman, J. A., \& Joyce, C. K. (2007). Innovation in services: Corporate culture and investment banking. California Management Review, 50(1), 174-191. https://doi.org/10.2307/41166422

Makadok, R. (2001). Towards a synthesis of resource-based and dynamic capability views of rent creation. Strategic Management Journal, 22(5), 387-402. https://doi.org/10.1002/smj.158

Matsuno, K., Mentzer, J. T., \& Ozsomer, A. (2002). The effect of entrepreneurial proclivity and market orientation on business performance. Journal of Marketing, 66(3), 18-32. https://doi.org/10.1509/jmkg.66.3.18.18507

Mazzarol, T., Clark, D. N., \& Rebound, S. (2014). Strategy in action: Case studies of strategy, planning and innovation in Australian SMEs. Small Enterprise Research, 21(1), 54-71. https://doi.org/10.1080/13215906.2014.11082076

Mbizi, R., Hove, L., Thondhlana, A., \& Kakava, N. (2013). Innovation in SMEs: A review of its role to organizational performance and SMEs operations sustainability. Interdisciplinary Journal of Contemporary Research in Business, 4(11), 370-389.

McClelland, D. C. (1961). The Achieving Society. Princeton, NY: D. Van Nostrand. https://doi.org/10.1037/14359-000

McDougall, P. P., \& Oviatt, B. M. (2000). International entrepreneurship: The intersection of two research paths. Academy of Management Journal, 43(5), 902-908. https://doi.org/10.2307/1556418

McGrath, R. G. (2001). Exploratory learning, innovative capacity, and managerial oversight. Academy of Management Journal, 44(1), 118-131. https://doi.org/10.2307/3069340

Miller, D. (1983). The correlates of entrepreneurship in three types of firms. Management Science, 29(7), 770 792. https://doi.org/10.1287/mnsc.29.7.770

Mueller, V., Rosenbusch, N., \& Bausch, A. (2013). Success patterns of exploratory and exploitative innovation: A meta-analysis of the influence of institutional factors. Journal of Management, 39(6), 1606-1636. https://doi.org/10.1177/0149206313484516

Nasution, H. N., Mavondo, F. T., Matanda, M. J., \& Ndubisi, N. O. (2011). Entrepreneurship: Its relationship with market orientation and learning orientation and as antecedents to innovation and customer value. Industrial Marketing Management, 40(3), 336-345. https://doi.org/10.1016/j.indmarman.2010.08.002

Ndubisi, N. O., \& Agarwal, J. (2014). Quality performance of SMEs in a developing economy: Direct and indirect effects of service innovation and entrepreneurial orientation. Journal of Business \& Industrial Marketing, 29(6), 454-468. https://doi.org/10.1108/JBIM-07-2013-0146

Ndubisi, N. O., Gupta, O. K., \& Ndubisi, G. C. (2005). The moguls' model of computing: Integrating the moderating impact of users' persona into technology acceptance model. Journal of Global Information Technology Management, 8(1), 27-47. https://doi.org/10.1080/1097198X.2005.10856389

Newbert, S.L. (2007). Empirical research on the resource-based view of the firm: An assessment and suggestions for future research. Strategic Management Journal, 28(2), 121-146. https://doi.org/10.1002/smj.573

Nieto, M.J., Santamaria, L., \& Fernandez, Z. (2015). Understanding the innovation behavior of family firms. Journal of Small Business Management, 53(2), 382-399. https://doi.org/10.1111/jsbm.12075

Nunnally, J. C., \& Bernstein, I. H. (1994). Psychometric Theory (3rd ed.). New York: McGraw-Hill.

OECD (2005). Oslo Manual: Proposed Guidelines for Collecting and Interpreting Technology Innovation Data. Paris: OECD. https://doi.org/10.1787/9789264013100-en

Prajogo, D., \& McDermott, C. M. (2014). Antecedents of service innovation in SMEs: Comparing the effects of external and internal factors. Journal of Small Business Management, 52(3), 521-540. https://doi.org/10.1111/jsbm.12047 
Roberts, P. W. (1999). Product innovation, product-market competition and persistent profitability in the U.S. Pharmaceutical industry. Strategic Management Journal, 20(7), 655-670. https://doi.org/10.1002/(SICI)1097-0266(199907)20:7<655::AID-SMJ44>3.0.CO;2-P

Saki, S., Shakiba, H., \& Savari, M. (2013). Study of the relationship between the organizational learning and organizational innovation at the university of Tehran. Journal of Organizational Learning and Leadership, $11(1), 1-18$.

Satorra, A., \& Bentler, P. M. (1988). Scaling corrections for chi square statistics in covariance structure analysis (pp. 208-313). American Statistics Association 1988 Proceedings of the Business and Economic Sections.

Street, C. T., \& Cameron, A. F. (2007). External relationship and the small business: A review of small business alliance and network research. Journal of Small Business Management, 45(2), 239-266. https://doi.org/10.1111/j.1540-627X.2007.00211.x

Tang, J., Tang, Z., \& Katz, J. A. (2014). Proactiveness, stakeholder-firm power difference, and product safety and quality of Chinese SMEs. Entrepreneurship: Theory \& Practice, 38(5), 1129-1157. https://doi.org/10.1111/etap.12029

Tang, Z., \& Hull, C. (2012). An investigation of entrepreneurial orientation, perceived environmental hostility, and strategy application among Chinese SMEs. Journal of Small Business Management, 50(1), 132-158. https://doi.org/10.1111/j.1540-627X.2011.00347.x

Teece, D. J., Pisano, G., \& Shuen, A. (1997). Dynamic capabilities and strategic management. Strategic $\begin{array}{lll}\text { Management Journal, } & \text { 509-533. }\end{array}$ https://doi.org/10.1002/(SICI)1097-0266(199708)18:7<509::AID-SMJ882>3.0.CO;2-Z

Teng, B. (2007). Corporate entrepreneurship activities through strategic alliances: A resource-based approach toward competitive advantage. Journal of Management Studies, 44(1), 119-142. https://doi.org/10.1111/j.1467-6486.2006.00645.x

Wernerfelt, B. (1984). A resource-based view of the firm. Strategic Management Journal, 5(2), 171-180. https://doi.org/10.1002/smj.4250050207

Wiklund, J., \& Shepherd, D. (2003). Knowledge-based resources, entrepreneurial orientation, and the performance of small and medium-sized business. Strategic Management Journal, 24(13), 1307-1314. https://doi.org/10.1002/smj.360

Yuan, K. W., Hermens, A., Huang, K. P., \& Chelliah, J. (2015). Entrepreneurial orientation and organizational learning on SMEs' innovation. The International Journal of Organizational Innovation, 7(4), 71-81.

Zahra, S. A., \& Garvis, D. M. (2000). International corporate entrepreneurship and firm performance: The moderating effect international environmental hostility. Journal of Business Venturing, 15(5/6), 469-492. https://doi.org/10.1016/S0883-9026(99)00036-1

Zhou, K. Z., Yim, C. K., \& David, K. T. (2005). The effects of strategic orientations on technology and market-based breakthrough innovations. Journal of Marketing, 69(2), 42-60. https://doi.org/10.1509/jmkg.69.2.42.60756

\section{Copyrights}

Copyright for this article is retained by the author, with first publication rights granted to the journal.

This is an open-access article distributed under the terms and conditions of the Creative Commons Attribution license (http://creativecommons.org/licenses/by/4.0/). 